\title{
A Study of Mythological and Philosophical Outlook of Keki N.Daruwalla
}

\author{
Dr. Shri Krishan Rai ${ }^{1}$, Goutam Karmakar ${ }^{2}$ \\ ${ }^{1}$ Department of Humanities and Social Sciences, National Institute of Technology Durgapur, West Bengal, India. \\ ${ }^{2}$ Department of Humanities and Social Sciences, National Institute of Technology Durgapur, West Bengal, India.
}

\begin{abstract}
A close reading of some of the poems of Keki N.daruwalla often projects his as a bard. He may be also called a repository of the legend of his reader and of the oral folk-lore. He has borrowed the tales from different epics, cultures and religion and put those into his verse to make his verse a telling commentary of different mythologies, legends and his verse has become philosophical and mythological in nature. In his poetry one can found tales from his Parsi background, from Hindu mythology and also from Greek, Islam, African and Judaism philosophy. But threads from Hindu mythology and Hindu philosophy are more prominent in him. In some pieces tales from Bible are also seen. As a result of all these his poetry becomes a medium through which he unveils many truth behind these mythologies and throws light on some particular Hindu philosophical foundations. Although he has a Parsi origin but the long time he spends in northern India allures him more to think about India and mythologies related to India.
\end{abstract}

Keywords: Mythology, Philosophy, Religion, Passion, River.

\section{INTRODUCTION}

Once T.S.Eliot spoke about poets as they are the persons who "concentrating upon a task in the same sense as the making of an efficient engine or the turning of a jug or a table leg." (Four Elizabethan Dramatists, Selected Essays, 24) Here Eliot talks about the mechanics of writing a poem. What he says that the poet must have the ability to transmute the words and ideas into his poetry. A poet is no less different with a painter because like a painter a poet works and plays with his words, imagination, inspiration and surroundings. And in the context of Indian English Poetry, Keki N.Daruwalla is one of the finest craftsmen in this sense. Actually Indian English poetry is in a large way indebted to him because of his remarkable contribution with poetry which has a vibrant quality and an aesthetic appeal. On Indian English literature his poetry casts scintillating and immense influence and with his poetic excellence he has obtained a noteworthy position in the matrix of Indian English poetry.

Daruwalla is a gifted poet who has a unique quality of compactness. He has the ability to shift his position between the concrete and abstract. He is chiefly lyrical with great power of expression and description. His poetic genius and endeavor cast a strong influence over younger poets because of his poetic device and technique. For this reason younger generation follows him in a vivid way. With his oblique and subtle poetry he tries to reflect humanism and naturalism with contemplation. His poetry truly shows Indian sensibility, life, past history and Indian surroundings. To bring out the under current of Indian life, his poetry upholds the very spirit and sensibility like an Indian. With multiple array of significance, with quintessence of Indianness, with thematic universality and excellence, he tries to expand his reader's imaginative range and in this context he comes closer to Nissim Ezekiel who is the father figure of Indian English poetry. In this context it is worth mentioning that Nissim Ezekiel once says about Daruwalla's poetry is "a fine blend of freedom and discipline, metrical rhythms and a word-order of prose, compact, harsh, alliterative phrasing and relaxed movement." (Ezekiel, 68)

What makes Daruwalla is one of the popular and well known poet are his innovative ideas and use of various themes. His range of subjects is never limited and he tries to cover different time spans in his poetry. His poetry may be called the storehouse where one can find Indian rich cultural past and more clearly the epics and mythological tales and legends. Also he is deeply influenced by the Hindu philosophy. His poetry never speaks of a golden tomorrow because his poetry is deeply rooted in the past and present. His poetry is coupled with the mundane experience with which he is familiar with. Actually with highest caliber of poetic acumen he tries to make his reader familiar with many mythological tales. He understands the pulse of Indian who are highly religious and believer of folk-tales and he tries to firm that belief or rather to deconstruct the myth.

\footnotetext{
${ }^{1}$ Corresponding Author: goutamkrmkr@gmail.com
} 
Daruwalla has emerged out to be an eminent Indian English Poet with twelve volumes of verse. Those are Under Orion (1970), Apparition in April (1971), Crossing of Rivers (1976) Winter Poems (1980), The Keeper of the Dead (1982), Landscapes (1987), A Summer of Tigers (1995), Night River (2000), Map Maker (2002), The Scarecrow and the Ghost (2004) Collected Poems 1970-2005 (2006), The Glass blower: Selected Poems (2008) and Fire Alter (2013). But mythology and influence of Hindu philosophy are not seen in every volume. In his very first book he shows his inclination towards mythologies. In his 'Dialogues with a Third Voice', one can find the touch of myths in the form of dramatic mythic monologues. Here he echoes with Ted Hughes who also deals with animals to construct a mythic framework. Depiction of animals is seen here and with the use of dramatic and lyric monologue he describes his subject matter. In the third section of the poem he tells:

"There is no time like myth-time:

Spurt of the taut grape

Cedar glooms

Fables of the sky

And fables of the earth

meeting on a young horizon.

Any time is myth-time

a tent of camel hide

flapping in the wind

bread and goatcheese

wine and the smoked meat of the lamb."

(Dialogue with a Third Voice)

Mythical projection of geographical landscape is shown in 'Shiva: At Timarsian'. Here he shows the ancient place and Shiva's concept with the use of vivid imagery. Myth here is associated with Shiva and here his use of words like 'Tandava', 'Aegle marmelos' prove this. Here the poet says:

"Lord of the stalactite

I have seen

icicles growing from your tonsure.

... some side-flicker from the divine

orgasm of the Tandava.

...Will you wear a raffia wig

and let them tame you, domesticate you

and pat your ice-cone sharpness

into a rounded lingam?" (Shiva: At Timarsian)

Appeared in 1971 entitled 'Apparition in April' contains some poems which show mythology and philosophy on a large scale. Here he throws light on two legends rather tragic figures from Indian epic Mahabharata. These two are Karna and Carvak. In his 'Carvak', Carvak is the profounder of Lokayat philosophy. Here Charvak standind still throws hot ash on the face of Yudhisthira and curses him. Everyone praises Yudhisthira because he wins the battle but Carvak is seen:

"He stands rooted, a father figure

his arm aloft, holding the tribesmen's curse

before he brings it down

hot ash on the victor's face. 
American Research Journal of Humanities and Social Sciences, Volume 1, Issue 3, 2015

ISSN 2378-7031

Then a stampede of moments

hoarse with blood-cries." (Carvak)

Here the poet is a believer of Carvak's philosophy which sometimes appears cynical and perversion for non-believer of his philosophy. But for Daruwalla, Carvak's philosophy is no less perverse because it has a firm ground and deep faith over own work. Actually Carvak is not in the side of meaningless rituals and for him 'Yagna-fire' and 'Shraddh' are nothing but Brahmin's way of income and all the divine hymns are the voice of Brahmins. These are really harsh truth and this philosophy is hard to accept for Brahmins. Carvak even does not believe in hell or heaven or the after life myth. The poet says:

"He had seen the lie embodied in pain

and the corrupt fantasy in the other-

a sidelong glance and he passed on

to the fire-alter

where they waited." (Carvak)

Carvak's slaying is very pitifully described in Santiparva of the Mahabharata bt Ved Vyasa. When Carvak curses Yudhisthir for killing his brethren, Yudhisthir wants to commit suicide. But the Brahmins cannot accept this as because this indicated their defeat. They become unable to counter the philosophy of Carvak and so they brand Carvak as a demon. They finally become violent and burn Carvak alive. But this gives finality to Carvak's philosophy and he is the ultimate winner in this argument before the readers. The poet says:

"As flesh and myth are ushered to the flame

you wind up like Kama.

The throng is curious

to see the star-clay burning in your blood

to smear their foreheads with the totem-ash.

No further tampering now

you are a finality

lean and charred,

only the stance is left." (Carvak)

In a poem of this volume 'Pilgrimage to Badrinath', he gain describes the geographical myth of a particular location. Indians are deeply religious and they want to undertake difficult journey to attain 'Punno'. The more difficult the root is then the more punno one can attain and the poet just describes one such difficult journey to Badrinath in this poem. This philosophy that Indian believes really surprising for the poet and also he here projects a Hindu mind's religious faith during this journey:

"Along the valley of the burning sun;

on flinty bridle-paths which centuries have trod

in penance and anonymous dust,

the caravan of pain proceeds towards God."

(Pilgrimage to Badrinath)

In his 'Karna' from this same volume 'Apparition in April' he describes this mythological figure from the epic Mahabharata. Karna is the outcome of the rape of virgin Kunti by Sun God as described by him. So Karna is the biological son of Kunti. The poet says:

"Sun-rape

the god descending 
from hi fire-chariot

a blade of light

burning through her

virginal membranes

and you were born

to the adolescent Kunti

a rape child by the Sun!" (Karna)

In this poem the poet praises Karna and places him in a position of one of the greatest warrior even better than Arjuna. He has given the full circle of Karna who is socially merginalised from the very beginning. Karna is possessed within the celestial armour from his birth and these armours and ear-rings are the boon from Sun-god which will protect him for forever and these armours are rooted in his body and flesh. Karna is also the universal giver with a larger heart and kindlier hand. When Lord Indra realizes that Arjuna can't defeat Karna then he comes in disguises as a Brahmin and alms these armours from Karna. Karna is really the heroic figure in Mahabharata and Daruwalla by glorying Karna wants to give Karna a larger than life character. He wants to create reverential attitude for Karna in everyone's heart. Karna is always seen from a negative point of view but he is actually the voice of the marginalized people and if he is given a chance then he can defeat everyone there in the battle. The poet says:

"armours one can take off

but this was shell-skin

rooted in flesh

and when you ripped it off

nerve-root and flesh-root

still clinging

in bleeding fidelity

$\ldots$ and handed to the Brahmin Indra

too late you discovered

that gods too have castes." (Karna)

The poet also shows the reader glimpses of the battlefield. He says that it is Lord Krishna who repeatedly saves Arjuna from Karna. Finally he is killed by Arjuna when he forgets all his training to protect and defend himself and chariot wheel is stuck in the mud. Really Karna is betrayed through out his life and those curses help him to attain his death. All these are predestined and it is not possible to forget Karna easily. The poet says in the concluding lines:

"Radheya you were dead

before the falcon-arrow found you.

... We can't forget you in a hurry." (Karna)

De-glorification of philosophy can also be seen in his 'Charity-3 Faces'. He says that according to Hindu philosophy one's own work asserts one's destiny and one's own life and afterlife depends on his own 'Karma'. But this karma can't help a diseased lady who is in distress condition. His rational mind and postmodern outlook questions about the authenticity of this philosophy and proves this irrelevant. This philosophy is no longer suits to the people who is in miserable condition and unable to resist human sufferings. He says here:

"I would believe in Karma itself and afterlife

if only her misery were not in a caricature 
American Research Journal of Humanities and Social Sciences, Volume 1, Issue 3, 2015

ISSN 2378-7031

if only I didn't associate

nirvana with that toothless grin

and those sockets smiling at the absence of the eyes."

(Charity-3 Faces)

Daruwalla's use of mythology and philosophy can be also seen in his third collection of poems namely 'Crossing of Rivers'. Here he portrays the river Ganges at Varanasi and the mythical background behind it. In the first part 'The Waterfront', the poet presents the purificatory myth of the holy river Ganges. In his 'Boat-Ride Along the Ganga', he shows how the ghats and surroundings are polluted and become vulnerable to disease, sufferings, decay and death. Here he points out about the tales of Dasasvamedh ghat where ancient kings of Bharasiva sacrifice ten horses. Such legendary tales are there as the poet says:

"Outlines blur in the apoplectic gloom

as the panda points out Dasasvamedh

I listen avidly to his legend-talk."

(Collected Poems,97)

In his 'Vignette ii', he refers to several rituals of Hindus and also myth is present here. Here also myth is associated with Hindu religion and bears a significance with it. Here one can see how goddess Durga destructs the the place of destruction becomes the place of wiorship. This deconstructiom paves the way for reconstruction. Here the poet mentions 'Panchganga ghat' which is the place where five rivers are connected. Here the poet says:

"You go the rounds of the Panchtirath

starting from the ghat where Durga

had dropped a sword

to where she dropped an earring

and the Panchganga Ghat where four rivers

are said to meet the Ganga

like this river of faith going down

the stone-steps to meet the river." (Vignette II)

In this volume Hindu philosophy is seen in a vivid way and also Hindu rituals are seen in these ghats. On those ghats moves on the general drama of death and life and this is called 'Samsara' according to Hindu religion. But also in this ghats rituals like 'Pinddan' shows the liberation and transcendence of human soul and this is called 'Moksha.' Actually the tile itself bears significance. Crossing of rivers of the soul is a concept rather Greek mythology where the dead crosses the Lethe river to go to the hell or heaven or to attain new body and this Greek mythology is associated with Hindu religion. Poet like Daruwaala can do this time of juxtaposition. In another sense crossing of river can be seen a kind of rituals to attain 'Punno' by the people and they call it 'Tirthas'. Actually Hindus love to travel the holy places and this tirthas like crossing places or fords is the place where earth and heaven meet and the cycle of death and birth continues. Here mythology, rituals and Hindu philosophy merge together.

Daruwalla is such a gifted craftsman that he uses mythology with nature to bring out the human passion so beautifully that some of the poems from his 'Landscapes' contain a fine texture. The scenic beauty of Verinag is portrayed in his 'Ruminations at Verinag'. Here he gives a mythical reference by telling that the place is important for being the place where Lord Shiva and Parvati physically unite. Here the poet gives this mythical reference in a mocking way to search the origin of the area. The poet says:

"They came in the summer-thirst of their passions,

Parvati and Shiva.

She asked for water, and when he found none

he stuck the mountain 
American Research Journal of Humanities and Social Sciences, Volume 1, Issue 3, 2015

ISSN 2378-7031

in the hot moon of his anger and the snout

appeared. The blue fame jetted out." (Ruminations at Verinag)

In his 'The Round of the Seasons', he uses myth to illustrate the human passion and its association to nature. In this poem he describes all the seasons and climates prevalent in India. In this poem he also describes how human passion changes in every climate. The second section of this poem is 'Grishma'. In This season sun is at its full fledge and scorching sunshine is everywhere. He shows this through the mythical god Kama. Here the poet appeals this god of lust to kindly allow eyes, aromatic hair and body from the clutch of scorching sunshine. Through the reference of this mythical figure, the poet describes the human feelings and passion like love and sex. Here the poet says:

"kama, in this torrid summer

let something remains cool

her eyes, reflecting the waters,

the smell of jasmine in her hair,

her body dripping with the cold river

as she steps out on the ghats.

If you need tapers at your alter, Kama,

Let her ardour burn." (The Round of the Seasons)

Daruwalla uses mythology, legendary figure and Hindu philosophy in his volume 'The Map Maker'. Feminism is also shown in his poetry. He has shown his concern for the second sex of the society. He has feelings for the subdued, marginalized and subjugated women and he shows this in his poetry. But here also he uses mythological figure like Draupadi from the epic Mahabharata. He says that woman like Draupadi are still suffering in the hand of cruel male dominated society. But also the ending lines create too much question for the readers. Here he says:

"The travails of Draupadi

are never ending.

it seems-some people have it

in their bleeding stars:

first exploited by the Pandavas,

five to one,

then by the Kauravas,

hundred to one

and now by the feminists

in millions." (Draupadi)

One section of 'The Map Maker' is 'Map Maker' and here his discussion of Hindu philosophy is shown in a particular poem namely 'The Birth of Maya'. For him philosophy is something through which human actions are denounced, directed, justified and adhered. It is one of the basic of society. Here the poet gives the description about the birth of Maya. At the beginning of the world, there was nothing in this world. Nothing concrete and only absolute truth is conceived. These all are described in 'Matsya Purana'. As the past was yet to born so forgetfulness, dream, energy, thought, eternity, infinity all are yet to born. The divine essence is only there and as a result death and birth are there as depicted in 'Matsya Purana'. In this situation everything is in a complex situation and concept of illusion rather 'Maya' comes into existence. At the center of illusion only Maya is the prime pivotal; deity which not only governs but also manifests and perpetuates dream and illusion in this world. So the philosophy of Maya followed by death and birth fins a place in his poetry. Here the poet says:

"There was nothing, neither air nor substance,

nor energy, nor either, 
not thought nor dream

...there was no eternity

because there was no time,

and no infinity.

And for a moment the Absolute forgot

its timeless identity;

and Maya leapt and shimmered

into ephemeral existence." (The Birth of Maya)

\section{CONCLUSION}

One of the conspicuous features of Indian English poetry is the use of mythology as a prominent theme in the poetry and Keki N.Daruwalla is no more exception in this case. Not only mythology, he also re interprets the Indian philosophies in his poetry. But he does not use it like his predecessor because with the passage of time everything needs modification. So his treatment of mythologies, his perception of Indian philosophies and his way of discussion regarding these also modified and he presents these in a beautiful way to serve his purposes. Being a poet of postmodern era, it is his duty to question the so called truth and he exactly does so by distorting the mythologies to attain new information. It may be also his attempt to reconstruct India's cultural past and values of Indian philosophies.

\section{REFERENCES}

[1] Daruwalla, Keki N. Apparition in April. Calcutta: Writers Workshop, 1971. Print.

[2] Collected Poems 1970- 2005. New Delhi: Penguin, 2006 Print.

[3] Crossing of Rivers. New Delhi: OUP, 1976. Print.

[4] Map Maker. New Delhi: Ravi Dayal, 2002. Print.

[5] The Keeper of the Dead. New Delhi: OUP, 1982. Print.

[6] Under Orion. Calcutta: Writers Workshop, 1970. Print.

[7] Winter Poems. New Delhi: Allied Publishers, 1980. Print.

[8] Sinha, R.N. The Poetry of Keki N. Daruwalla. New Delhi: B. R. Publishing Corporation, 2002. Print.

[9] Pandey, Birendra(ed.). Indian Poetry in English. New Delhi: Atlantic Publishers and Distributors, 2001. Print.

[10] King, Bruce. Modern Indian Poetry in English. New Delhi: Oxford University Press, 1987. Print.

[11] Naik, M.k. Dimentions of Indian English Literature. New Delhi: Sterling Publishers, 1984. Print.

[12] Singh, R.A. The Poetry of Keki.N.Daruwalla. Jaipur: Book Enclave, 2002. Print. 